Chirurgia (2020) 115: 39-49

No. 1, January - February

Copyright $@$ Celsius

http://dx.doi.org/10.21614/chirurgia.115.1.39

\title{
The Importance of Systemic Inflammation Markers in the Survival of Patients with Complicated Colorectal Cancer, Operated in Emergency
}

\author{
Georgiana Bianca Constantin1', Dorel Firescư ${ }^{2,3}$, Dragoș Voicu' ${ }^{2}$ Bogdan Ștefănescu ${ }^{2,3}$, Raul Mihailov', \\ Cristina Serban $^{2,3}$, Eugenia Panaitescu', Rodica Bîrlă' ${ }^{1,4}$, Silviu Constantinoiu ${ }^{1,4}$ \\ ${ }^{1}$ Carol Davila University of Medicine and Pharmacy, Bucharest, Romania \\ 2Dunarea de Jos University, Faculty of Medicine and Pharmacy, Galati, Romania \\ ${ }^{3}$ Clinical Emergency County Hospital Sf. Ap. Andrei, Galati, Romania \\ ${ }^{4}$ General and Esophageal Surgery Department, Center of Excellence in Esophageal Surgery, Saint Mary Clinical Hospital, Bucharest, Romania
}

Corresponding author:

Rodica Birla, MD

General and Esophageal Surgery Department, Center of Excellence in Esophageal Surgery, Sf. Maria Clinical Hospital, Bucharest, Romania E-mail: birlarodica@ahoo.com

\section{Abbreviations:}

NLR = Neutrophil-to-lymphocyte ratio, $\mathrm{PLR}=$ platelet-to-lymphocyte ratio,

$\mathrm{LMR}=$ lymphocyte-to-monocyte ratio, $\mathrm{PNI}=$ prognostic nutritional index, $\mathrm{CRP}=\mathrm{C}$ reactive protein

$\mathrm{HR}=$ hazard ratio

$\mathrm{Cl}=$ confidence interval,

VEGF = vascular endothelial growth factor,

TIL = tumor-infiltrating lymphocytes, $\mathrm{TLS}=$ tertiary lymphoid structures, TNF $\alpha=$ tumoral necrosis factor $\alpha$ IL-1=interleukine-1.

Received: 07.01.2020 Accepted: 15.02 .2020

\section{Rezumat}

Markerii de inflamație sistemică - factori de prognostic la pacienții cu cancer colorectal complicat, operati în urgență

Introducere: Răspunsul inflamator joacă un rol critic în carcinogeneză. Există scoruri recente bazate pe răspunsul inflamator sistemic, cum ar fi raportul neutrofile/limfocite (NLR), raportul trombocite/limfocite (PLR), raportul limfocite/monocite (LMR), despre care s-a arătat că au valoare prognostică la pacienții cu cancer. Aceste scoruri permit identificarea pacienților care vor avea un răspuns slab la tratament şi o supravietuire de scurtă durată. Scopul acestui studio este de a evalua rolul prognostic al NLR, PLR, LMR şi PNI în termeni de supraviețuire la distanță pentru bolnavii cu cancer colorectal, operați în urgență.

Material şi Metode: Am inclus în studiu 391 de pacienți internați şi operați pentru cancer colorectal complicat în clinica Chirurgie II a Spitalului Clinic Județean de Urgență "Sf. Ap. Andrei” din Galați, în perioada 2008-2017. Am analizat factorii paraclinici de inflamație sistemică NLR, PLR, LMR şi PNI.Ca factori de prognostic, au fost analizate curbele de supraviețuire.

Rezultate: La pacienții din lot, valorile crescute ale NLR, precum şi ale PLR au dus la creşterea riscului de deces (HR=7,581, 95\% $\mathrm{CI}=(6.358,9.039), \mathrm{p}$ value $=0.000000$, respective $\mathrm{HR}=1.043,95 \%$ $\mathrm{CI}=(1.039,1.047), \mathrm{p}$ value $=0.000000)$, iar valorile crescute ale LMR şi PNI au condus la scăderea acestui risc $(\mathrm{HR}=0.069,95 \%$ 
$\mathrm{CI}=(0.054,0.090), \mathrm{p}$ value $=0.000000$, respective $\mathrm{HR}=0.758,95 \% \mathrm{CI}=(0.730,0.788), \mathrm{p}$ value $=0.000000)$. În analiza de regresie multivariată, creşterea PLR a determinat o creştere a riscului de apariție a decesului $(\mathrm{HR}=1.024,95 \% \mathrm{CI}=(1.019,1.029)$, $\mathrm{p}$ value $=0.000000)$, iar pentru $\mathrm{LMR}$ şi pentru PNI, o reducere a riscului de deces $(\mathrm{HR}=0.353,95 \% \mathrm{CI}=(0.248,0.504), \mathrm{p}$ value $=0.000000$, respective $\mathrm{HR}=0.852,95 \% \mathrm{CI}=(0.822,0.883), \mathrm{p}$ value $=0.000000)$.

Concluzii: Analiza univariată a arătat că NLR şi PLR sunt factori de risc, iar LMR şi PNI sunt factori de protecție în ceeace priveşte supraviețuirea. Analiza multivariată a relevant că PLR este factor de risc independent, iar markerii LMR şi PNI au fost factori de protecție independenți.

Cuvinte cheie: cancer colorectal, urgență, marker inflamație, supraviețuire

\section{Abstract}

Introduction: The inflammatory response plays a critical role in carcinogenesis. There are recent scores based on the systemic inflammatory response, such as neutrophil/lymphocyte ratio (NLR), platelet/lymphocyte ratio (PLR), lymphocyte/monocyte ratio (LMR), which have been shown to have prognostic value in cancer patients. These scores allow the identification of patients who will have poor response to treatment and poor survival.

The aim of this study is to evaluate the prognostic role of NLR, PLR, LMR and PNI in terms of long-term survival in patients with colorectal cancer, operated in emergency.

Material and Methods: We included 391 patients admitted and operated for complicated colorectal cancer in the Surgery II clinic of the Clinical Emergency County Hospital "Sf. Ap. Andrei " from Galati, between 2008-2017. We analyzed the paraclinical factors of systemic inflammation NLR, PLR, MRL and PNI. As prognostic factors, survival curves were analyzed.

Results: The high values of NLR and PLR increased the risk of death ( $\mathrm{HR}=7.581,95 \% \mathrm{CI}=$ $(6.358,9.039), \mathrm{p}$ value $=0.000000$, respectively $\mathrm{HR}=1.043,95 \% \mathrm{CI}=(1.039,1.047), \mathrm{p}$ value $=$ $0.000000)$, and the increased values of LMR and PNI led to the decrease of this risk (HR $=0.069$, $95 \% \mathrm{CI}=(0.054 .0 .090), \mathrm{p}$ value $=0.000000$, respectively $\mathrm{HR}=0.758,95 \% \mathrm{CI}=(0.730 .0 .788), \mathrm{p}$ value $=0.000000)$. In the multivariate regression analysis, the increase of PLR resulted in an increase in the risk of death $(\mathrm{HR}=1.024,95 \% \mathrm{CI}=(1.019 .1 .029), \mathrm{p}$ value $=0.000000)$, and for the LMR and PNI, a reduction of the risk of death $(\mathrm{HR}=0.353,95 \% \mathrm{CI}=(0.248 .0 .504), \mathrm{p}$ value $=0.000000$, respectively $\mathrm{HR}=0.852,95 \% \mathrm{CI}=(0.822 .0 .883), \mathrm{p}$ value $=0.000000)$.

Conclusions: The univariate analysis showed that NLR and PLR are risk factors, and LMR and PNI are protective factors in terms of survival. The multivariate analysis revealed that PLR is an independent risk factor, and LMR and PNI were independent protection factors.

Key words: colorectal cancer, emergency, inflammation markers, survival

\section{Introduction}

The preoperative nutritional and immunological status have a strong impact on the estimation of the survival of neoplastic patients (1). The inflammatory response plays an important role in carcinogenesis process and a number of cells involved in the inflamtion process and innate signaling molecules of the immune system are involved in tumor progression (2).

The first description of the link amid inflammation and tumorigenesis was made by Virchow in 1881 (3), and since then there has been growing evidence to support this finding.

Inflammation is now considered to be a 
distinctive sign for cancer development (4). Current evidence refers to the fact that inside a tumor it exists alongside cancer cells, base structures (eg, extracellular matrix), cells that don't trigger the immune system (eg, fibrous tissue cells) and immune cells, respectively basophils,lymphocytes,eosinophils, mast cells, NK cells and dendritic cells, which interact and contribute to an extremely immunosuppressive microenvironment. Lymphocytes play an essential role in this habitat, as the gradual growth of lymphocytes inside the tumor is directly associated with anticancer activity (5-7).

On the other way, necrosis and tissue hypoxia (8) can lead to complex interactions between altered cells and the nonspecific inflammatory reaction, facilitating the evolution of the disease (9). This systemic inflammatory response involves changes in the hematopoietic and neuroendocrine system, energy and protein metabolism, and liver function. The liver cells synthesize and discharge into the systemic circulation acute phase proteins that are linked with lymphocytopenia and affected T lymphocyte response in the tumor cells, destroying cell-mediated immunity (10). To estimate the systemic inflammatory response, platelets, lymphocytes, serum levels of neutrophils, albumin and C-reactive protein, either individual or in several blendings, were used as prognostic factors for patients with different malignant solid tumors.

Until recently, the most used parameter for evaluating the SIRS in patients with cancer was the increased level of CRP. However, there are recent scores based on the inflammatory response, such as neutrophil/lymphocyte ratio (NLR), platelet/lymphocyte ratio (PLR), lymphocyte/monocyte ratio (MRL), which have been shown to have prognostic value in cancer patients. These scores allow identification of patients who will have poor response to treatment and poor survival (11).

Given the correlation between inflammatory status and prognosis of neoplasms, more and more research is being made in order to understand how the prognosis of cancer patients can be assessed by simple blood tests (12).
Cell-mediated inflammatory response, lymphocytes, neutrophils and monocytes are increasingly recognized as having an important role in carcinogenesis.

In colorectal cancer, lymphocytes have a major task in the immune response, as systemic inflammation forcefuly decreases cellular immunity, resulting in a significant cutback in CD4 + lymphocytes and an increase in CD8 + suppressive T lymphocytes (13).

Some immunocytes, including neutrophils, can produce vascular endothelial growth factor (VEGF), which, by angiogenesis, promotes tumor development (14).

In this context, the relationship between neutrophils and lymphocytes becomes very useful to analyze and most of the studies recognize its role as a prognostic marker in cancer (15). Zahorec (16) was the first author to report the link between NLR and disease severity as a prognostic factor in critically ill patients. Various studies evaluating the relationship between NLR and colorectal cancer have shown that NLR is a strong prognostic factor. For colorectal cancer patients it is assumed that NLR is a combined indicator of both inflammation and immune status.

Lymphocytes play a vital role in cytotoxic cell death and cytokine production, which in turn prevent the proliferation and metastasis of malignant cells (17). Studies on lymphocytes are contradictory, but most have shown that lymphocytes decrease in patients with advanced colon cancer (18).

PLR is the ratio of platelets to lymphocytes. The mechanisms underlying the association between PLR with elevated values and poor prognosis in colorectal cancer are not fully known. Recent studies have shown that platelets can prevent tumor cell death by natural-killer cells and that platelets can secrete angiogenic and tumor growth factors (GF), including vascular endothelial GF and platelet-derived GF, and thus promote growth, progression and tumor spread (19-21). Furthermore, thrombocytosis has been promoted to be linked with poor prognosis in colorectal cancer $(22,23)$. 
LMR is the ratio between the total number of lymphocytes and the number of monocytes. Lymphocytes are involved in cytotoxic cell death and inhibition of tumor cell proliferation and migration $(24,25)$. Lymphopenia usually indicates the severity of the disease and can cause cancer cells to escape the immunity of tumor-infiltrating lymphocytes (TILs) (26). TILs are composed of lymphocytes that migrate into the tumor microenvironment (27). Low levels of TILs have been shown to predict poorer survival in colorectal cancer patients (28). In contrast, monocytes can promote tumor progression and metastasis (29). Several proinflammatory cytokines, produced by the monocytes, are associated with poor prognosis in cancer patients, such as TNF- $\alpha$ and IL-1 (30). In addition, tumor-associated macrophages, derived from circulating monocytes, play a role in suppressing immunity and promoting angiogenesis, invasion, and migration (31) Thus, the decrease in LMR could be affiliated with poor prognosis for patients diagnosticated with cancer.

Hypoalbuminemia is a risk factor for the survival of patients with colon cancer (32). PNI, calculated taking into account the serum albumin level and the number of peripheral lymphocytes, reflects both the nutritional and immune status of the patient (33). PNI has recently been shown to be a predictive marker for both postoperative complications and prognosis of colorectal cancer patients (34).

The target of our study is to assess the prognostic role of NLR, PLR, LMR and PNI in terms of long-term survival in patients with colorectal cancer, operated in emergency.

\section{Material and Methods}

We included 391 patients admitted and operated for complicated colorectal cancer in the Surgery II clinic of the Clinical Emergency County Hospital "Sf. Ap. Andrei" from Galati, between 2008-2017. Patient data were collected from clinical observation reports and operating protocols. We analyzed the following paraclinical systemic inflammation factors: NLR, PLR, LMR and PNI.
Neutrophil-to-lymphocyte ratio (NLR), lymphocyte-to-monocyte ratio (LMR), plateletto-lymphocyte ratio (PLR) and PNI nutritional prognosis index (calculated with the equation $10 \mathrm{x}$ serum albumin $(\mathrm{g} / \mathrm{dl})+0.005 \mathrm{x}$ total lymphocyte count $\left(\right.$ per $\left.\mathrm{mm}^{3}\right)$ ) are markers of systemic inflammation. The determination of the values of these markers was made considering the laboratory results performed at admission.

As prognostic factors, the survival curves were analyzed, following the involvement of the inflammation factors in the distance survival in the Cox univariate and multivariate regression analysis. We defined the overall survival as the period since the moment of diagnosis to the date of bereavement or until the deadline of the study (01.10.2019).

The curves for the overall survival were estimated by the Cox method, and the comparison for the statistical significance with the sig.p-value test with $95.0 \% \mathrm{CI}$. The analysis of the Univariate Cox proportional risk ratio (HR) was performed to identify potential prognostic factors, and that of the Cox multivariate proportional risk ratio (HR) to evaluate the independent prognostic factors. The accuracy of the prognostic factors was analyzed by evaluating the sensitivity and specificity of these markers after establishing the cut off values, using the ROC curves. Statistical study was calculated using the SPSS 23.0 program from Windows Software. Statistical conclusions were made considering a statistically significant difference $p$ value $<0.05$ for all calculations performed.

\section{Results}

The univariate analysis of Cox proportional hazards reports revealed that NLR and PLR are risk factors in terms of survival $(\mathrm{HR}=$ $7.581,95 \%$ CI $=(6.358,9.039)$, p_value $=$ 0.000000 , respectively $\mathrm{HR}=1.043,95 \% \mathrm{CI}=$ $(1.039,1.047), p$ value $=0.000000)$, and LMR and PNI are protective factors $(\mathrm{HR}=0.069$, $95 \% \mathrm{CI}=(0.054,0.090), \mathrm{p}$ value $=0.000000)$ 
and respectively $(\mathrm{HR}=0.758,95 \% \mathrm{CI}=(0.730$, $0.788), \mathrm{p}$ value $=0.000000)($ Table 1$)$.

The ROC curve designed for NLR in discriminating death in the 391 patients involved in the study (379 deceased (96.93\%) and 12 survivors (3.07\%)) has the area of 0.859 with $95 \%$ CI of (0.821 to 0.892$)$, p_value $=<$ 0.001 . The cutoff point is $>2.61$, with a sensitivity of 73.61 and a specificity of 100.00 . (Table 2, Fig. 1).

The average survival time in patients with NLR values below 2.61 was $39.676,95 \% \mathrm{CI}=$ $(37.189,42.163)$ and in those with values above 2.61 it was $12.504,95 \% \mathrm{CI}=(11.747,13.261)$, the difference between time of survival being statistically significant (p_value $=0.000000$, Log-Rank) (Table 2, Fig 2).

The area of the ROC curve designed for PLR was 0.866 with $95 \%$ CI of (0.828 to 0.898), p_value $=<0.001$. The cutoff point is $>139.85$ with the sensitivity of 78.89 and the specificity of 100.00 (Table 2, Fig. 3).

The average survival time in patients with

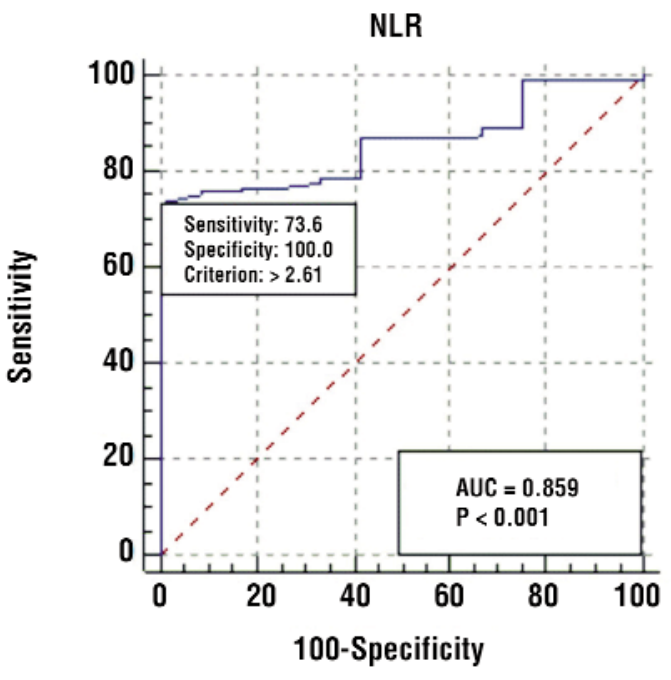

Figure 1. ROC curve for NLR

PLR values below 139.85 was $41,7046,95 \%$ CI $=(39,041,44,368)$ and in those with values above 139.85 it was $13,294,95 \% \mathrm{CI}=(12,466$, $14,121)$, the difference being statistically

Table 1. Survival univariate and multivariate analysis of systemic inflammation markers

\begin{tabular}{ccccc}
\hline Prognostic factor & \multicolumn{2}{c}{ Univariate } & \multicolumn{2}{c}{ Multivariate } \\
\hline HLR & HR(95\%Cl) & P_value & HR(95\%Cl) & P_value \\
\hline PLR & $7.581(6.358,9.039)$ & 0.000000 & & \\
\hline LMR & $1.0431 .039,1.047)$ & 0.000000 & $1.024(1.019,1.029)$ & 0.000000 \\
\hdashline PNI & $0.069(.054, .090)$ & 0.000000 & $0.353(0.248,0.504)$ & 0.000000 \\
\hline
\end{tabular}

Table 2. Survival analysis of systemic inflammation markers with cutoff value

\begin{tabular}{|c|c|c|c|c|c|c|}
\hline Prognostic factor & Deaths & Sensitivity & Specificity & $\begin{array}{c}\text { Mean -Estimate } \\
\text { HR(95\% Cl) }\end{array}$ & $\begin{array}{l}\text { Univariate } \\
\text { Log-Rank }\end{array}$ & p_value \\
\hline $\begin{array}{l}\text { NLR } \\
\leq 2.61 \\
>2.61\end{array}$ & $\begin{array}{c}94 / 104 \\
285 / 286\end{array}$ & 73.61 & 100.00 & $\begin{array}{l}39.676 \\
12.504\end{array}$ & $\begin{array}{c}(37.189,42.163) \\
(11.747,13.261)\end{array}$ & 0.000000 \\
\hline $\begin{array}{l}\text { PLR } \\
\quad \leq 139.85 \\
>139.85\end{array}$ & $\begin{array}{c}79 / 90 \\
300 / 301\end{array}$ & 78.89 & 100.00 & $\begin{array}{l}41.704 \\
13.294\end{array}$ & $\begin{array}{l}(39.041,44.368) \\
(12.466,14.121)\end{array}$ & 0.000000 \\
\hline $\begin{array}{l}\text { LMR } \\
\leq 2.28 \\
>2.28\end{array}$ & $\begin{array}{l}250 / 250 \\
129 / 141\end{array}$ & 66.75 & 100.00 & $\begin{array}{l}11.128 \\
35.231\end{array}$ & $\begin{array}{l}(10.512,11.744) \\
(32.886,37.576)\end{array}$ & 0.000000 \\
\hline $\begin{array}{l}\text { PNI } \\
\leq 39.5 \\
>39.5\end{array}$ & $\begin{array}{l}221 / 221 \\
158 / 170\end{array}$ & 60.69 & 100.00 & $\begin{array}{l}10.647 \\
31.741\end{array}$ & $\begin{array}{l}(10.038,11.256) \\
(29.449,34.033)\end{array}$ & 0.000000 \\
\hline
\end{tabular}




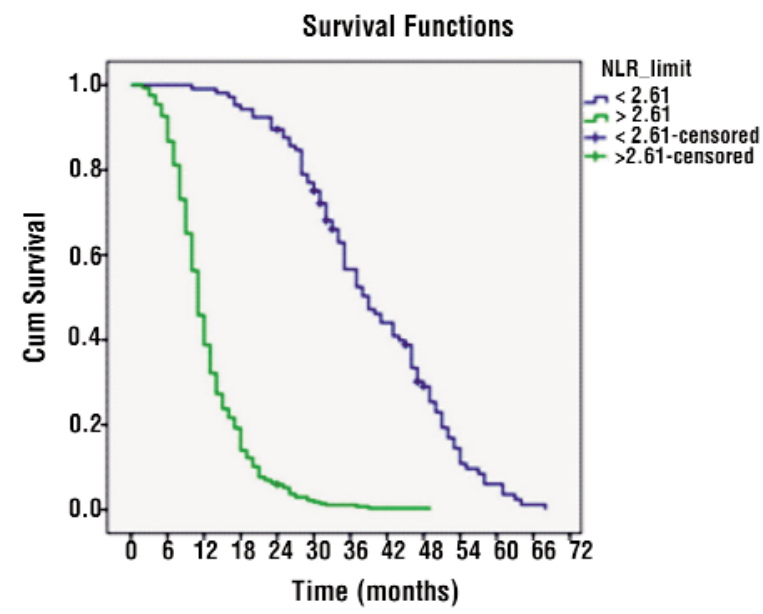

Figure 2. Survival curves for NLR with cutoff value

significant $(\mathrm{p}$ _value $=0.000000$, Log-Rank $)$ (Table 2, Fig. 4).

The area of the ROC curve designed for LMR was 0.837 with $95 \%$ CI of (0.797 to $0.872)$, p_value $=<0.001$. The cutoff point is $<2.28$, with a sensitivity of 66.75 and a specificity of 100.00 (Table 2, Fig. 5).

The average survival time in patients with LMR values below 2.28 was $119,128,95 \% \mathrm{CI}=$ $(10,512,11,744)$ and in those with values above 2.28 it was $35231,95 \%$ CI $=(32,886$, $37,576)$, the difference being statistically significant (p_value $=0.000000$, Log-Rank) (Table 2, Fig. 6).

The area of the ROC curve designed for

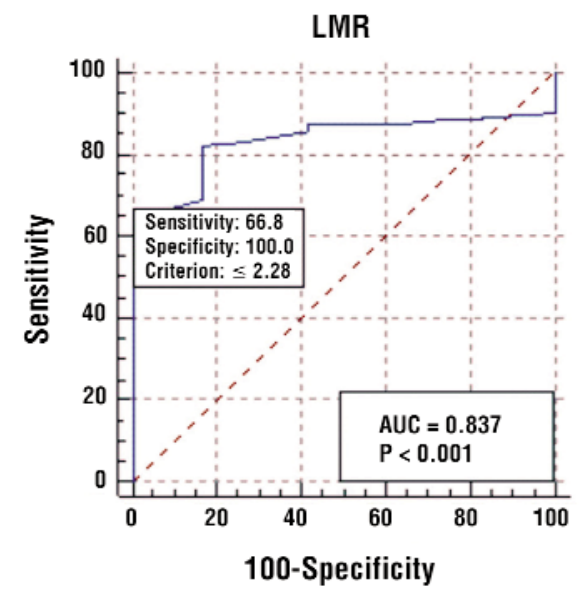

Figure 5. ROC curve for LMR

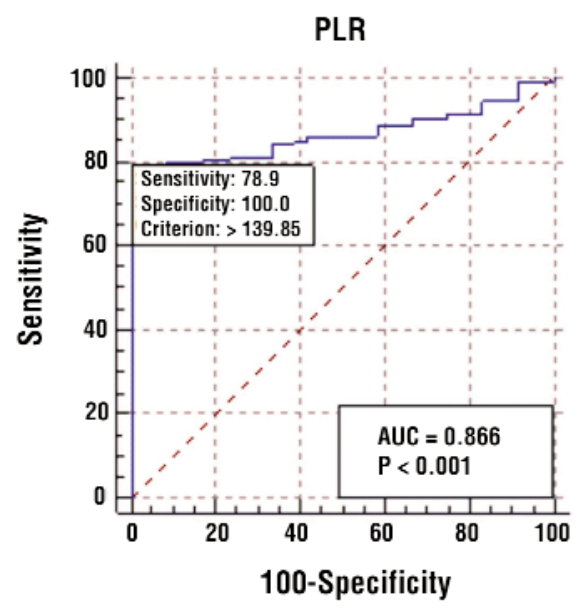

Figure 3. ROC curve for PLR

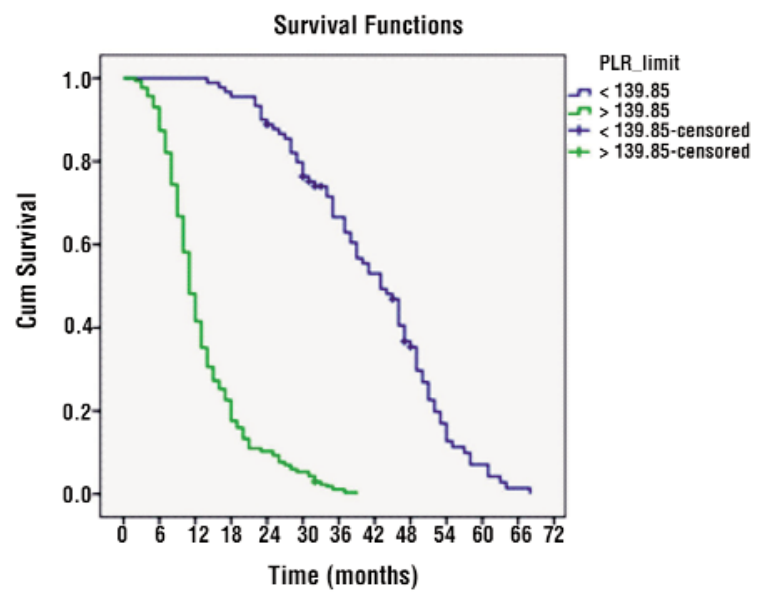

Figure 4. Survival curves for PLR with cutoff value

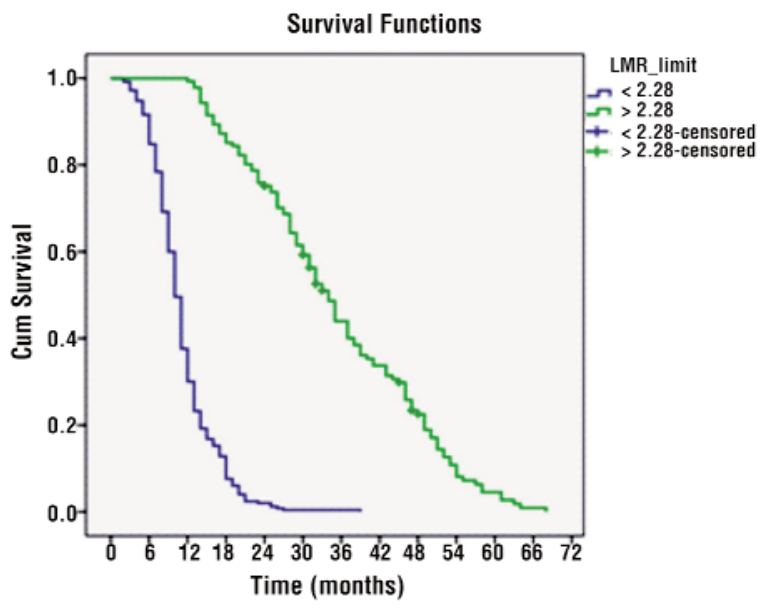

Figure 6. Survival curves for LMR with cutoff value 
PNI was 0.787 , with $95 \% \mathrm{CI}=(0.743$ to 0.827$)$, p_value $=<0.001$. The cutoff point is $\leq 39.5$, with the sensitivity of 60.69 and the specificity of 100.00 (Table 2, Fig. 7).

The average survival time in patients with PNI values below 39.5 was $10,647,95 \% \mathrm{CI}=$ $(10,038,11,256)$ and in those with values below 39.5 it was $31,741,95 \% \mathrm{CI}=(29,449$, $34,033)$, the difference being statistically significant (p_value $=0.000000$, Log-Rank) (Table 2, Fig. 8).

Of the potential factors selected in the univariate analysis, in the multivariate analysis, regarding PLR, its increase leads to an increased risk of death $(\mathrm{HR}=1.024,95 \% \mathrm{CI}=$ $(1.019,1.029), \mathrm{p}$ value $=0.000000)$, this being a factor of independent risk, and for LMR and PNI, their increase leads to a lower risk of death $(\mathrm{HR}=0.353,95 \% \mathrm{CI}=(0.248,0.504), \mathrm{p}$ value $=$ $0.000000)$, respectively $(\mathrm{HR}=0.852,95 \% \mathrm{CI}=$ $(0.822,0.883), \mathrm{p}$ value $=0.000000)($ Table 2$)$, so they are independent protection factors.

\section{Discussions}

In the last years, numerous studies have been made that have demonstrated the connection between systemic inflammatory response and malignancies and, moreover, there is increasing evidence that inflammatory markers may influence the prognosis of neoplastic patients.

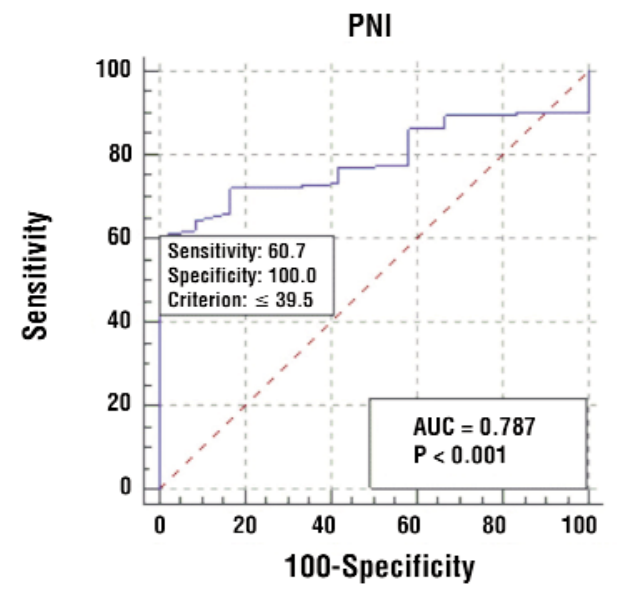

Figure 7. ROC curve for PNI
The chronic systemic inflammatory response is involved in the nutritional and functional decline of cancer patients with the natural course of the disease. Evaluation of this response using markers of systemic inflammation allows the identification of patients at high risk (11).

Regarding the SIR in patients with complicated colorectal cancer, our study showed that:

- inflammatory markers NLR and PLR with increased values are risk factors, while increased values of LMR and PNI are protective factors for survival, as the univariate analysis has shown;

- PLR with high value was an independent risk factor in the multivariate analysis and LMR and PNI were independent protection factors.

All the markers analyzed in this study are calculated with formulas that involve the total number of lymphocytes. The anti-tumor immune response is orchestrated by cytotoxic $\mathrm{T}$ lymphocytes, which have the capacity to inhibit tumor growth (35). Small lymphoid groups, which contain both T lymphocytes and B lymphocytes, called tertiary lymphoid structures (TLS), have been detected in tumors and associated with a strong lymphocyte response and a good prognosis (36).

NLR has been suggested to reflect the balance between pro-tumor inflammation and anti-tumor immune function (37). An

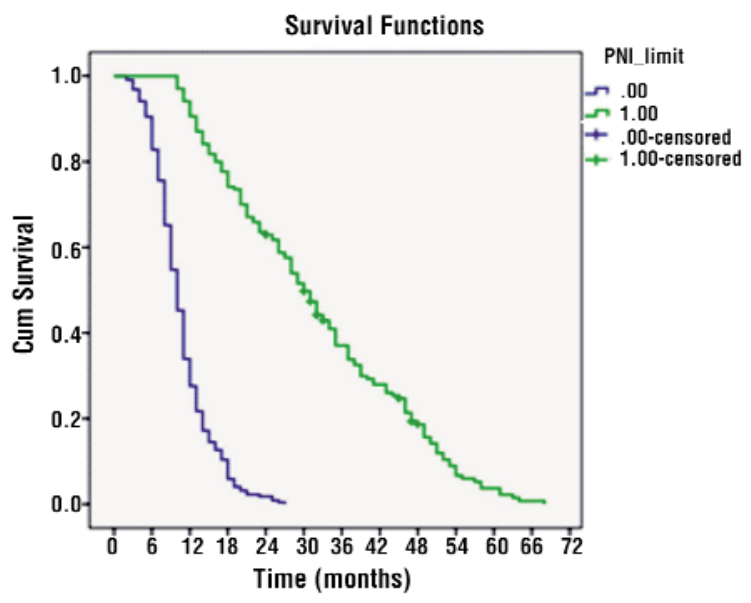

Figure 8. Suvival curves for PNI with cutoff value 
increased NLR may be the outcome of one of the following: increase in neutrophils, or a decrease in lymphocytes or both. In the tumor microenvironment, an increased number of neutrophils favors tumor expansion, while a decrease in lymphocyte number indicates inefficient local tumor limitation. Thus, an elevated microenvironmental NLR may indicate tumor expansion, representing an factor of adverse prognosis. Because serum NLR is an easily measurable, reproducible and cheap marker, it may have a major clinical effect in practice in the future (38).

We have shown that the increased preoperative value of NLR was a risk factor for remote survival, as other authors have also found (39-41). In a single study conducted in 2018 at the University of Leeds in the UK, the authors reported that high NLR values were associated with a high risk of death in univariate but not multivariate analysis (42).

Many studies have reported the prognostic value of inflammatory markers $\operatorname{NLR}(43,44)$, LMR (18,45), PNI (46), PCR (47), but a consensus on the prognostic value of PLR has not been reached.

Ozawa et al. (48), Kwon et al. (49) and Liu $\mathrm{H}$ et al. (50) showed that PLR with high values is a risk factor in colorectal cancer, a fact that we also found in our study, while other authors did not find statistical significance in this association in any of the groups that they analyzed (patients with non-metastatic colorectal cancer at different stages and patients with liver metastases) $(51,52)$. Emir et al. (53) found statistical significance in the association between PLR with increased value and 5-year survival in single- and multivariate analyzes performed on 140 patients with resectable colorectal cancer.

In our study, we showed that PLR with high values was an independent risk factor in the multivariate analysis, unlike other authors, who reported that PLR is a risk factor, but not independent (54).

In the publications, there is a growing enthusiasm in finding the verge value of markers of systemic inflammation over which the probability of death increases significantly (55-58).

The cutoff values for NLR and PLR in our study were 2.61 , respectively 139.85 , values close to those reported in other studies.

In a recent meta-analysis, which included 23 studies (11762 patients), it is shown that increased NLR and PLR values are risk factors for colorectal cancer patients. The cutoff values for NLR and PLR were 3 and 150 respectively (59). Other authors have calculated the cutoff value of 4.7 for NLR (60) or even $5(61,62)$.

The cutoff values for PLR as a prognostic factor differ a lot in the literature. In some studies, the reported value was 130 (63), and in other studies included in a meta-analysis, the cutoff value for PLR was 150 (64), different from the one we calculated in our study.

The value of the ratio of lymphocytes to monocytes is also a biomarker of the host's immune response. Recent evidence suggests that the preoperative value ofLMR may be prognostic in colorectal cancer (65).

In a retrospective study involving 3281 patients treated in the Northern Sydney Local Health District, it was found that increased MRL was associated with better survival. The authors concluded that LMR is an independent predictor for survival period in patients diagnosticated with colorectal tumors with curative resections and appears to be superior to pre-existing biomarkers (18). A metaanalysis that included the results of 15 retro- $^{-}$ spective observational studies, including 11783 patients, indicates that a high LMR value was a significant predictive factor for better survival (66), which we also found in our study.

In some other published works, the a evaluation of the predictionstrenght of the LMR in metastatic tumors revealed similar results, but in the multivariate analysis it did not prove to be an independent prognostic factor (67).

The cutoff value for LMR varies widely in different studies, from 2.14 (68) to 3.78 (69). Some authors calculated the cutoff value for LMR very close to that of our study $(2,28,70,71)$. 
The literature data regarding the prognostic value of the PNI index seem to be the most consistent. In several studies it has been shown that PNI with high preoperative values is a protective factor in univariate analyzes and an independent protection factor in colorectal cancer patients in multivariate analyzes (72).

A retrospective study that included 1321 colorectal cancer patients showed that patients with low preoperative PNI were associated with more aggressive tumors, advanced stages of the disease, with lymph node metastases and 5-year survival poorer than patientswith high PNI values. In this study, PNI was also an independent prognostic factor. The authors concluded that the preoperative PNI is a simple and useful marker for predicting the outcomes of colorectal cancer patients, including with respect to long-term survival, so it should be included in the routine preoperative analyzes of these patients (1).

The cutoff value for PNI variesquite a bit in the studies analyzed: 44.5 (73), 45 (1), values generally higher than those calculated by us (39.5). We appreciate that we can put this fact on account of the more pronounced hypoalbuminemia and lymphocytopenia in patients operated in emergency for complicated tumors.

In the last years, many studies have been published regarding the prognostic value of different markers of systemic inflammation for colorectal cancer patients, but very few have included patients operated in emergency.We consider that in this situation, the analysis of these markers could be even more useful, given the fact that we are talking about immunocompromised, neoplastic patients, who have a precarious biological condition, with operatios made in bad local conditions (unprepared colon) or in conditions of generalized peritonitis, with septic shock.

Future prospective studies will be needed to verify the significance of these prognostic markers in clinical practice. The analysis of markers of systemic inflammation is convenient, simple and cost-effective. Their routine evaluation could be useful in assessing the prognosis of patients with colorectal cancer, operated in emergency.

\section{Conclusions}

Prognostic scores based on inflammation, such as NLR, PLR, LMR and PNI, results of the SIR, have been associated with survival in patients with colorectal tumors.

In the univariate analysis, we found that the high values of NLR and PLR are risk factors, and the high values of LMR and PNI are protective factors for the survival of patients with colorectal tumors, operated in emergency.

The increased value of PLR is an independent risk factor for patients in the group, while the increased values of LMR and PNI are protective independent survival factors.

\section{Conflicts of Interests}

The authors declare no conflicts of interests.

\section{References}

1. Jian-Hui C, Iskandar EA, CaiShl, Chen CQ, Wu H, He YL. Significance of Onodera's prognostic nutritional index in patients with colorectal cancer: a large cohort study in a single Chinese institution. Tumour Biol. 2016;37(3):3277-83.

2. Coussens LM, Werb Z. Inflammation and cancer. Nature. 2002; 420:860-867

3. Virchow R. An address on the value of pathological experiments. $\mathrm{Br}$ Med J. 1881;2:198-203

4. Hanahan D, Weinberg RA. Hallmarks of cancer: the next generation. Cell. 2011:144:646-74

5. Pedrazzani C, Mantovani G, Fernandes E, Bagante F, Luca Salvagno G, Surci N. et al. Assessment of neutrophil-to-lymphocyte ratio, platelet-to-lymphocyte ratio and platelet count as predictors of long-term outcome after RO resection for colorectal cancer. Sci Rep. 2017;7:1494.

6. Gregory AD, Houghton AM. Tumor-associated neutrophils: new targets for cancer therapy. Cancer Res. 2011;71:2411-6

7. Albini A, Sporn MB. The tumour microenvironment as a target for chemoprevention.Nat Rev Cancer. 2007;7:139-47

8. Vakkila J, Lotze MT. Inflammation and necrosis promote tumour growth. Nat Rev Immunol. 2004;4:641-8

9. DeNardo DG, Johansson M, Coussens LM. Immune cells as mediators of solid tumor metastasis. Cancer Metastasis Rev. 2008; 27:11-8

10. Roxbourgh CSD, McMillan DC. Role of systemic inflammatory response in predicting survival in patients with primary operable cancer.Future Oncol. 2010;6:149-63

11. McMillan DC. Systemic inflammation, nutritional status and 
survival in patients with cancer.CurrOpinClinNutrMetab Care. 2009; 12(3):223-6.

12. Lee JS, Kim NY, Na SH, Youn YH, Shin CS. Reference values of neutrophil-lymphocyte ratio, lymphocyte-monocyte ratio, plateletlymphocyte ratio, and mean platelet volume in healthy adults in South Korea. Medicine (Baltimore). 2018;97(26):e11138.

13. Ying $H Q$, Deng $Q W$, He BS, Pan $Y Q$, Wang $F$, Sun $H L$ et al. The prognostic value of preoperative NLR, d-NLR, PLR and LMR for predicting clinical outcome in surgical colorectal cancer patients. MedOncol. 2014; 31:305

14. Balkwill FR,Mantovani A. Cancer-related inflammation: common themes and therapeutic opportunitiesSemin Cancer Biol 2012; 22:33-40

15. Socorro Faria Sara, César Fernandes Jr P, José Barbosa Silva M, Lima VC, Fontes Wagner, Freitas-Junior R, et al.The neutrophil-toIymphocyte ratio: a narrative review. ecancer 2016;10:702

16. Zahorec R. Ratio of neutrophil to lymphocyte counts-rapid and simple parameter of systemic inflammation and stress in critically ill. BratisILek Listy. 2001;102:5-14

17. Mallappa S, Sinha A, Gupta S, Chadwick SJ. Preoperative neutrophil to lymphocyte ratio \&gt; 5 is a prognostic factor for recurrent colorectal cancer. Colorectal Dis. 2013;15:323-328.

18. Chan JC, Chan DL, Diakos CI, Engel A, Pavlakis N, Gill A, Clarke SJ. The Lymphocyte-to-Monocyte Ratio is a Superior Predictor of Overall Survival in Comparison to Established Biomarkers of Resectable Colorectal Cancer. Ann Surg. 2017;265:539-546

19. Palumbo JS, Talmage KE, Massari JV, La Jeunesse CM, Flick MJ, Kombrinck KW et al. Platelets and fibrin(ogen) increase metastatic potential by impeding natural killer cell-mediated elimination of tumor cells. Blood.2005;105:178-185

20. Gay LJ, Felding-Habermann B. Contribution of platelets to tumour metastasis.Nat Rev Cancer. 2011;11:123-134.

21. Tsuji T, Sawai T, Yamashita H. Platelet-derived endothelial cell growth factor expression is an independent prognostic factor in colorectal cancer patients after curative surgery. Eur J Surg Oncol. 2004;30:296-302

22. Sasaki K, Kawai K, Tsuno NH, Sunami E, Kitayama J. Impact of preoperative thrombocytosis on the survival of patients with primary colorectal cancer. World J Surg. 2012;36:192-200

23. Ishizuka M, Nagata H, Takagi K, Iwasaki Y, Kubota K. Preoperative thrombocytosis is associated with survival after surgery for colorectal cancer. J SurgOncol.2012;106:887-891

24. Terzic J, Grivennikov S, Karin E, Karin M.Inflammation and colon cancer. Gastroenterology 2010;138:2101-14.e2105

25. Lin EY, Pollard JW. Role of infiltrated leucocytes in tumour growth and spread.Br J Cancer 2004;90:2053-8

26. Waldner M, Schimanski CC, Neurath MF. Colon cancer and the immune system: the role of tumor invading $\mathrm{T}$ cells. World $\mathrm{J}$ Gastroenterol 2006;12:7233-8

27. Colotta F, Allavena P, Sica A, Garlanda C, Mantovani A.Cancer-related inflammation, the seventh hallmark of cancer: links to genetic instability. Carcinogenesis 2009;30:1073-81

28. Huh JW, Lee JH, Kim HR. Prognostic significance of tumor-infiltrating Iymphocytes for patients with colorectal cancer. Arch Surg 2012;147:366-72

29. Mantovani A, Allavena P, Sica A, Balkwill F. Cancer-related inflammation. Nature 2008:454:436-44.

30. Anand M, Chodda SK, Parikh PM,Nadkarni JS. Abnormal levels of proinflammatory cytokines in serum and monocyte cultures from patients with chronic myeloid leukemia in different stages, and their role in prognosis. HematolOncol 1998;16:143-54

31. Condeelis J, Pollard JW. Macrophages: obligate partners for tumor cell migration, invasion, and metastasis. Cell 2006;124:263-6

32. Lai CC, You JF, Yeh CY, Chen JS, Tang R, Wang JY, Chin CC. Low preoperative serum albumin in colon cancer: a risk factor for poor outcome. Int J Colorectal Dis. 2011 Apr;26(4):473-81.

33. Yang Y, Gao P, Chen X, Song Y, Shi J, Zhao J et al. Prognostic sig- nificance of preoperative prognostic nutritional index in colorectal cancer: results from a retrospective cohort study and a metaanalysis. Oncotarget.2016;7:58543-58552

34. Tokunaga R, Sakamoto Y, Nakagawa S, Miyamoto Y, Yoshida N, Oki E et al. Prognostic Nutritional Index Predicts Severe Complications, Recurrence, and Poor Prognosis in Patients With Colorectal Cancer Undergoing Primary Tumor Resection. Dis Colon Rectum. 2015; 58:1048-1057

35. Edin S., Kaprio T., Hagström J, Larsson P, Mustonen H, Bockelmann C et al.The Prognostic Importance of CD20+ B lymphocytes in Colorectal Cancer and the Relation to Other Immune Cell subsets.Sci Rep 2019;9,19997

36. Sautes-Fridman C, Lawand M, Giraldo NA, Kaplon H, Germain C, Fridman WH et al. Tertiary Lymphoid Structures in Cancers: Prognostic Value, Regulation, and Manipulation for Therapeutic Intervention. Front Immunol 2016;7, 407

37. Maeda K, Shibutani M, Otani H, Nagahara H, Ikeya T, Iseki Y, et al. Inflammation-based factors and prognosis in patients with colorectal cancer. World J GastrointestOncol. 2015;7:111-7

38. Tsai PL, Su WJ, Leung WH, Lai CT, Liu CK. Neutrophil-lymphocyte ratio and CEA level as prognostic and predictive factors in colorectal cancer: a systematic review and meta-analysis. J Cancer Res Ther. 2016;12:582-9

39. Borazan E, Balık AA, Bozdağ Z, Arik MK, Aytekin A, Yilmaz L et al. Assessment of the relationship between neutrophil lymphocyte ratio and prognostic factors in non-metastatic colorectal cancer. Turk J Surg. 2017;33(3):185-189

40. Ding PR, An X, Zhang RX, Fang YJ, Li LR, Chen G, et al. Elevated preoperative neutrophil to lymphocyte ratio predicts risk of recurrence following curative resection for stage IIA colon cancer. Int J Colorectal Dis. 2010;25:1427-1433

41. Chen $X Q$, Xue CR, Hou P, Lin BQ, Zhang JR. Lymphocyte-tomonocyte ratio effectively predicts survival outcome of patients with obstructive colorectal cancer. World J Gastroenterol. 2019;25(33): 4970-4984

42. Palin RP, Devine AT, Hicks G, Burke D. Association of pretreatment neutrophil-lymphocyte ratio and outcome in emergency colorectal cancer care. Ann R CollSurg Engl. 2018 Apr;100(4):308-315

43. Sun J, Chen $X, G a o ~ P$, Song $Y$, Huang $X$, Yang $Y$ et al. Can the neutrophil to lymphocyte ratio be used to determine gastric cancer treatment outcomes? A systematic review and meta-analysis.Dis Markers. 2016;2016:7862469

44. Del Prete M, Giampieri R, Loupakis F, Prochilo T, Salvatore L, Faloppi $L$ et al. Prognostic clinical factors in pretreated colorectal cancer patients receiving regorafenib: implications for clinical management. Oncotarget.2015;6:33982-33992

45. Gu L, Li H, Chen L, Ma X, Li X, Gao Y et al. Prognostic role of lymphocyte to monocyte ratio for patients with cancer: evidence from a systematic review and meta-analysis. Oncotarget. 2016;7: 31926-31942

46. Yang $Y$, Gao $P$, Chen $X$, Song $Y$, Shi J, Zhao J et al. Prognostic significance of preoperative prognostic nutritional index in colorectal cancer: results from a retrospective cohort study and a metaanalysis. Oncotarget.2016;7:58543-58552

47. Woo HD, Kim K, Kim J. Association between preoperative C-reactive protein level and colorectal cancer survival: a metaanalysis. Cancer Causes Control.2015;26:1661-1670.),

48. Ozawa T, Ishihara S, Nishikawa T, Tanaka T, Tanaka J, Kiyomatsu T et al. The preoperative platelet to lymphocyte ratio is a prognostic marker in patients with stage II colorectal cancer. Int J Colorectal Dis. 2015;30:1165-1171

49. Kwon HC, Kim SH, Oh SY, Lee S, Lee JH, Choi HJ et al. Clinical significance of preoperative neutrophil-lymphocyte versus plateletlymphocyte ratio in patients with operable colorectal cancer. Biomarkers.2012;17:216-222

50. Liu H, DU X, Sun P, Xiao C, Xu Y, Li R. Preoperative plateletlymphocyte ratio is an independent prognostic factor for resectable 
colorectal cancer. NanfangYikeDaxueXuebao. 2013;33:70-73

51. Li Y, Jia H, Yu W, Xu Y, Li X, Li Q, Cai S. Nomograms for predicting prognostic value of inflammatory biomarkers in colorectal cancer patients after radical resection. Int J Cancer. 2016;139:220-231.

52. Baranyai Z, Krzystanek M, Jósa V, Dede K, Agoston E, Szász AM et al. The comparison of thrombocytosis and platelet-lymphocyte ratio as potential prognostic markers in colorectal cancer. Thromb Haemost.2014:111:483-490

53. Emir S, Aydin M, Can G, Bali I, Yildirim 0, Öznur M et al. Comparison of colorectal neoplastic polyps and adenocarcinoma with regard to NLR and PLR. Eur Rev Med Pharmacol Sci. 2015;19:3613-3618

54. He W, Yin C., Guo G, Jiang C, Wang F, Qiu H et al. Initial neutrophil lymphocyte ratio is superior to platelet lymphocyte ratio as an adverse prognostic and predictive factor in metastatic colorectal cancer. Med Oncol 2013;30:439

55. Malietzis G, Giacometti M, Askari A, Nachiappan S, Kennedy RH, Faiz OD et al. A preoperative neutrophil to lymphocyte ratio of 3 predicts disease-free survival after curative elective colorectal cancer surgery. Ann Surg. 2014;260:287-92

56. Chiang SF, Hung HY, Tang R,Changchien CR, Chen JS, You YT et al. Can neutrophil-to-lymphocyte ratio predict the survival of colorectal cancer patients who have received curative surgery electively? Int J Color Dis. 2012;27:1347-57.

57. Shin JS, Suh KW, Oh SY. Preoperative neutrophil to lymphocyte ratio predicts survival in patients with T1-2N0 colorectal cancer. J SurgOncol. 2015;112:654-7

58. Jankova L, Dent OF, Chan C, Chapuis P, Clarke SJ. Preoperative neutrophil/lymphocyte ratio predicts overall survival but does not predict recurrence or cancer-specific survival after curative resection of node-positive colorectal cancer. BMC Cancer. 2013;13:442

59. Zhang J, Zhang HY, Li J, Shao XY, Zhang CX. The elevated NLR, PLR and PLT may predict the prognosis of patients with colorectal cancer: a systematic review and meta-analysis. Oncotarget. 2017;8(40):68837-68846

60. Dimitriou N., Felekouras E., Karavokyros I, Alexandrou A, Pikoulis E, Griniatsos J. Neutrophils to lymphocytes ratio as a useful prognosticator for stage II colorectal cancer patients. BMC Cancer 2018;18:1202

61. Haram A, Boland MR, Kelly ME, Bolger JC, Waldron RM, Kerin MJ. The prognostic value of neutrophil-to-lymphocyte ratio in colorectal cancer: a systematic review. J SurgOncol. 2017;115:470-9

62. Malietzis G, Giacometti M, Kennedy RH, Athanasiou T, Aziz O, Jenkins JT. The emerging role of neutrophil to lymphocyte ratio in determining colorectal cancer treatment outcomes: a systematic review and meta-analysis. Ann Surg0ncol. 2014;21:3938-46

63. Lu C, Gao P, Yang Y, Chen X, Wang L, Yu D et al. Prognostic evaluation of platelet to lymphocyte ratio in patients with colorectal cancer. Oncotarget. 2017;8(49):86287-86295. Published 2017 Sep 21.

64. Huang XZ, Chen WJ, Zhang X, Wu CC, Zhang CY, Wu J. An elevated platelet-to-lymphocyte ratio predicts poor prognosis and clinicopathological characteristics in patients with colorectal cancer: a meta-analysis. Disease Markers 2017;1:1-10

65. Nishijima TF, Muss HB, Shachar SS, Tamura K, Takamatsu Y. Prognostic value of lymphocyte-to-monocyte ratio in patients with solid tumors: a systematic review and meta-analysis. Cancer Treat Rev 2015;41:971-8

66. Tan D, Fu Y, Tong W, Li F. Prognostic significance of lymphocyte to monocyte ratio in colorectal cancer: A meta-analysis. Int J Surg. 2018;55:128-138

67. Neal CP, Cairns V, Jones MJ, Masood MM, Nana GR, Mann CD et al. Prognostic performance of inflammation-based prognostic indices in patients with resectable colorectal liver metastases. Med Oncol.2015;32:144

68. Stotz M, Pichler M, Absenger G,Szkandera J, Arminger F, SchaberlMoser $\mathrm{R}$ et al. The preoperative lymphocyte to monocyte ratio predicts clinical outcome in patients with stage $\mathrm{III}$ colon cancer. $\mathrm{Br}$ J Cancer 2014;110:435-40

69. Xiao WW, Zhang LN, You KY, Huang R, Yu X, Pei-Rong D et al. A low lymphocyte-to-monocyte ratio predicts unfavorable prognosis in pathological T3NO rectal cancer patients following total mesorectal excision. J Cancer 2015;6:616-22

70. Kozak MM, von Eyben R, Pai JS, Anderson EM, Koong A, Chang DT. The prognostic significance of pretreatment hematologic parameters in patients undergoing resection for colorectal cancer. Am J ClinOncol 2015

71. Neal CP, Cairns V, Jones MJ, Masood MM, Nana GR, Mann CD et al. Prognostic performance of inflammation-based prognostic indices in patients with resectable colorectal liver metastases. Med Oncol 2015;32:144

72. Luvian-Morales J, Gonzalez-Trejo S, Carillo J, Herrera-Goepfert R, Aiello-Crocifoglio V, Gallardo-Rincon D et. al. Association of the prognostic nutritional index and overall survival in patients with colorectal cancer: A STROBE compliant retrospective cohort study. Cancer Med.2019;8(7):3379-3388.

73. Manikam NR, Kristian Y, Lidwina L, Sari AD, Sunardi D. Prediction of Post-operative Survival of Colorectal Cancer Patient By Using the Prognostic Nutritional Index: An Evidence-Based Case Report. World Nutrition Journal 2019; 2(2):25-31 